\title{
Abraham Joshua Heschel and Nostra Aetate: Shaping the Catholic Reconsideration of Judaism during Vatican II
}

\author{
Joshua Furnal \\ Faculty of Philosophy, Theology, and Religious Studies, Radboud University, \\ Erasmusplein 1, 6525 HT Nijmegen, The Netherlands; j.furnal@ftr.ru.nl \\ Academic Editors: Douglas James Davies and Michael J. Thate \\ Received: 6 March 2016; Accepted: 30 May 2016; Published: 8 June 2016
}

\begin{abstract}
Although Nostra Aetate is only comprised of five short paragraphs, this document represents a turning point, not just for Catholic-Jewish relations, but also sketches the fundamental aims of embodying the Christian faith in a pluralistic age. There is a complex but important narrative that needs to be revisited so that we do not forget the ways in which Catholic learning has developed, and how this development has often been prompted by non-Catholics. In this article, I will re-examine some crucial details in the back-story of the formulation of Nostra Aetate and offer some observations about the potential consequences of omitting these details. My argument is that some recent events and scholarship suffer from a form of amnesia about the role that Jewish people have played in the development of Catholic learning - a form of amnesia that manifests in explicit proselytizing tendencies. In particular, I want to highlight the role that Rabbi Abraham Joshua Heschel played during the Second Vatican Council as an instructive example for Catholic-Jewish dialogue today.
\end{abstract}

Keywords: Abraham Joshua Heshel; Nostra Aetate; Vatican II; Judaism; Pope Francis; inter-faith dialogue

On the 50th anniversary of the Second Vatican Council, it is important not to forget about one of the Council's shortest but most significant declarations about the Church's relationship to other faiths. In the recent past, one could think that the shared spiritual patrimony of Christians and Jews highlighted in Nostra Aetate (1965) has been forgotten entirely. ${ }^{1}$ In 2008, Pope Emeritus Benedict XVI reintroduced the Tridentine prayer for Good Friday, which says "illumine [Jewish] hearts, so that they will recognize Jesus Christ, the Savior of all men". ${ }^{2}$ In 2009, the US Bishops issued a statement saying that "the whole people of Israel" will be included into the Church. In the same year, Benedict XVI brought Richard Williamson (a Holocaust denying bishop) back into fold, who was later excommunicated this year by Pope Francis. It would seem that despite all the recent Catholic-Jewish engagement, the legacy and teaching of Nostra Aetate is still haunted by forgetfulness.

Although Nostra Aetate is only comprised of five short paragraphs, this document represents a turning point not just for Catholic-Jewish relations, but also sketches new ways of articulating the relationship between Christians and non-Christians. There is a complex but important story that needs to be revisited so that we do not forget the ways in which Catholic learning has developed, and how this development has often been prompted by non-Catholics. In this short essay, I will re-examine

1 “Nostra Aetate." Available online: http://www.vatican.va/archive/hist_councils/ii_vatican_council/documents/vat-ii_ decl_19651028_nostra-aetate_en.html (accessed on 3 June 2016) [1].

2 Pope Benedict XVI rewrote this prayer and inserted it into the pre-Vatican II Tridentine Mass text. It was placed under the heading "pro conversio iudaeorum", which is still very problematic. For more, see [2] John T. Pawlikowski. "Defining Catholic Identity against the Jews: Pope Benedict XVI and the Question of Mission to the Jewish People." In Trialogue and Terror: Judaism, Christianity, and Islam after 9/11. Edited by Alan L. Berger. Eugene: Cascade Books, 2012 , chap. 7. 
some crucial details in the back-story of the formulation of Nostra Aetate and offer some observations about the potential consequences of omitting these details. My argument is that some recent events and scholarship suffer from a form of amnesia about the role that Jewish people have played in the development of Catholic learning - a form of amnesia that manifests in explicit proselytizing tendencies. In particular, I want to highlight the role that Rabbi Abraham Joshua Heschel played during the Second Vatican Council as an instructive example for Jewish-Catholic dialogue today. Prior to the Second Vatican Council, Abraham Heschel had a long history of collaboration between Jews and Catholics and other Christians in France, Central Europe, Great Britain and the United States. It was not something that Heschel decided to begin once the Council was underway. Therefore, the inter-continental and inter-faith story behind the formation of its sentences is dramatic and, for Catholics especially, worth remembering-especially in light of recent reforms by Pope Francis. ${ }^{3}$

\section{The Contested Legacy of Nostra Aetate}

Indirectly set in motion by Pope John XXIII, Nostra Aetate was the first official document that recognized the search for meaning, holiness, and truth among the various religions of the world. ${ }^{4}$ From a Jewish perspective, Nostra Aetate was seen as revolutionary because it repudiated the centuries-long oppression of Jewish people by Church Councils. ${ }^{5}$ In fact, this document was the first time that anti-Semitism was condemned by a Council, and the Jewish people were acknowledged uniquely as God's chosen people. Today, this may seem like an uncontroversial declaration. Yet, as John Connelly has shown, a re-examination of the history of the Roman Catholic Church during this era reveals that this position was hardly uncontroversial. ${ }^{6}$ After establishing the "Kingdom of Christ" heralded in Quas Primas (1925) by signing the Lateran Treaty with Mussolini in 1929, no mention is made of the Jews or a disavowal of anti-Semitism in Pope Pius XI's encyclical Non abbiamo bisogno (1931) [9]:

In everything that We have said up to the present, We have not said that We wished to condemn the [Fascist] party as such. Our aim has been to point out and to condemn all those things in the programme and in the activities of the party which have been found to be contrary to Catholic doctrine and Catholic practice, and therefore irreconcilable with the Catholic name and profession. And in doing this We have fulfilled a precise duty of Our episcopal ministry towards Our dear sons who are members of the party, so that their conscience may be at peace ([1931], n. 62). ${ }^{7}$

Yet after signing the concordat with Hitler, Pius XI says in Mit brennender Sorge (1937) [10] that:

Whoever exalts race, or the people, or the State, or a particular form of State, or the depositories of power, or any other fundamental value of the human community-however

3 For more on Heschel's interfaith relations after World War II and his influence on Pope Francis, see [3-5]. Harold Kasimow. Interfaith Activism: Abraham Joshua Heschel and Religious Diversity. Eugene: Wipf and Stock, 2015, esp. chap. 8. See also, Harold Kasimow, and Byron L. Sherwin, eds. No Religion Is an Island: Abraham Joshua Heschel and Interreligious Dialogue. Maryknoll: Orbis, 1991. Also see, Michael Signer's essay "Body and Soul: Interreligious Dialogue" in Abraham Joshua Heschel: Philosophy, Theology and Interreligious Dialogue. Edited by Stanislaw Krajewski and Adam Lipszyc. Wiesbaden: Harrassowitz, 2009, pp. 181-87.

4 Although Pope John XXIII did not request that a document be created, he did establish the Secretariat for Promoting Christian Unity and appointed Cardinal Augustin Bea to be president a few days before the meeting with Jules Isaac. The pope asked Isaac to discuss his memorandum with Bea. Only later was it decided that Bea would facilitate reflection on the relations between the Church and the Jewish people in the Council. It was out of this process that a document would be developed. For more on the relation between the AJC, Bea, and Heschel, see [6] Reuven Kimelman. "Rabbis Joseph B. Soloveitchik and Abraham Joshua Heschel on Jewish-Christian Relations." Modern Judaism 24 (2004): 251-71.

5 Consider the anti-Jewish legislation in the Councils of Vannes, Epaone, Orleans, Lateran IV, and Florence discussed and defended at length in [7] Gavin D'Costa. Vatican II: Catholic Doctrines on Jews and Muslims. Oxford: Oxford University Press, 2014 , chap. 3.

6 For more see [8] John Connelly. From Enemy to Brother: The Revolution in Catholic Teaching on the Jews (1933-1965). Cambridge: Harvard University Press, 2012.

7 “Non abbiamo bisogno." Available online: http://w2.vatican.va/content/pius-xi/en/encyclicals/documents/hf_p-xi_ enc_29061931_non-abbiamo-bisogno.html (accessed on 3 June 2016) [9]. 
necessary and honorable be their function in worldly things - whoever raises these notions above their standard value and divinizes them to an idolatrous level, distorts and perverts an order of the world planned and created by God; he is far from the true faith in God and from the concept of life which that faith upholds ([1937], n. 8). ${ }^{8}$

Nevertheless, prior to Nostra Aetate, a rejection of anti-Semitism had not been made official teaching of the Church by a Council. The extensive commentary on the formulation of Nostra Aetate was written by Johannes Oesterreicher (who was himself a Jewish convert to Catholicism). ${ }^{9}$ The story that Oesterreicher tells can give the false impression that this document had always been motivated solely by Catholic concerns and the heroes in this story were nearly all eventually members of sub-committees in the Roman Curia. ${ }^{10}$ To a certain extent, there are some Catholics that deserve honorable mention despite the effects of the tumultuous history of Catholicism during the 1930s. For instance, it is heartening to learn that when he was the Vatican diplomat to Istanbul, Giuseppe Roncalli forged baptismal documents for Jews in Turkey to escape Nazi extermination camps. ${ }^{11}$ After the War in 1959, as Pope John XXIII, he removed the anti-Jewish language from the Good Friday liturgy (perfidia Iudaica). One year later, John XXIII set up the possibility for an official document on Catholic-Jewish relations to be formulated, appointing Cardinal Augustin Bea to oversee the Secretariat for Christian Unity and charging him to draft the document. Bea was a renowned Hebrew Bible scholar, the rector of the Biblicum, and the confessor of Pope Pius XII. However, we need to attend to Bea's efforts during this time period to break out of the Curia's insular mindset because it often involved relying upon Jewish scholars, and especially Rabbi Heschel.

By 1960, Jewish concerns had already been brought to the attention of the Pope regarding false statements about Israel, the collective guilt of the Jews, and the punishment of Jews for the crucifixion of Jesus. ${ }^{12}$ For instance, the French historian Jules Isaac gave the Pope an extract of The Tridentine Catechism (1566) which emphasized the guilt of all sinners as the cause of the crucifixion of Jesus-indicating that this is the view that needs to be recovered in public discourse because the charge of deicide (God-killers) has been used as justification for the murder of the Jewish people.

In response to Jewish efforts, there was a consensus emerging in Rome that "the Jews" were not responsible for the death of Jesus, yet there was still the assertion that Christians were the true heirs of Abraham (Gal 6:16), and there remained the eschatological hope of a Jewish conversion to Christianity (Rom 11:15, 25)..$^{13}$ This proselytizing position gets threaded through Oesterreicher's commentary on how the Council itself treated such issues even though there were others that altered this position in slightly different ways. ${ }^{14}$ The competing positions emerged through four drafts of the document and a comparison of them reveals how the Council Fathers went back-and-forth on this issue. The explicit proselytizing tendencies of the early draft of Nostra Aetate is often overlooked, especially since

8 "Mit brennender Sorge." Available online: http://w2.vatican.va/content/pius-xi/en/encyclicals/documents/hf_p-xi_enc_ 14031937_mit-brennender-sorge.html (accessed on 3 June 2016) [10].

9 [11] John Oesterreicher. "Declaration on the Relationship of the Church to Non-Christian Religions." Commentary on the Documents of Vatican II 3 (1967): 1-136.

10 Although Oesterreicher focuses on the hierarchy and other Roman Catholic clergy members in his Commentary, he does briefly mention the contribution of Jews and Protestants. However, he does not give them the proper attention that they deserve.

11 [12] Massimo Faggioli. John XXIII: Medicine of Mercy. Collegeville: Liturgical Press, 2014, chap. 4.

12 (Oesterreicher 1967: 2).

13 This is the position presented on 24 April 1960 in a petition signed by the Jesuit professors at the Biblicum to urge the Council to address "the problem of the people of Israel" when the Council addresses ecumenical matters (Oesterreicher 1967: 8-9) [11].

14 For instance in 1961, Gregory Baum presents a revision at a meeting in Ariccia Italy on 6-9 February. Baum inserts a rejection of anti-Semitism and the view that sees Jews as an accursed race (Oesterreicher 1967: 18) [11]. 
it contradicts the final draft of Nostra Aetate. ${ }^{15}$ What can account for this shift away from an emphasis upon proselytizing Jewish people in an attempt convert them to Christianity?

In his recent book on Vatican II, Gavin D'Costa neglects this shift altogether and claims that Nostra Aetate "implicitly taught that mission to the Jewish people was appropriate". ${ }^{16}$ Much of what D'Costa reads as the summation of "Council teaching" on the destiny of world religions is a privileged reading of Lumen Gentium 16 and Ad Gentes 7, and a subordination of the canonical status of Nostra Aetate as a second-class Council document. For instance, D'Costa defends his claim by drawing a distinction between ethnicity and religion: according to D'Costa, the Church repudiates anti-Semitism, but promotes non-coercive mission toward Jewish people despite the fact that many subsequent post-conciliar documents firmly reject this position. ${ }^{17}$ So this raises an important question: is this what Nostra Aetate explicitly teaches? Nostra Aetate does not even use the word "mission" in the text, instead, it encourages "mutual understanding and respect". ${ }^{18}$ Nostra Aetate explicitly teaches that Jewish people are not guilty of Christ's death nor are they "rejected or accursed by God", and re-emphasizes "the spiritual patrimony" that is shared across the covenants. Then why are some Catholics theologians still encouraging the continuation of proselytizing efforts? Reading D'Costa's remarks, one might recall a fierce debate from over a decade ago about a document from the US Catholic Bishops entitled Reflections on Covenant and Mission and the responses to Cardinal Avery Dulles. ${ }^{19}$ However, the question that still lingers is whether or not this entails a revocation of what Nostra Aetate teaches? The hope of "one accord" expressed in n. 4 leaves this task up to God, not the Church. By emphasizing the "ultimate inexpressible mystery" shared across covenants ([1965], n. 1), a different interpretation of Romans 9-11 is affirmed regarding the salvation of Israel without evoking the certainty of knowing how Israel will be saved. ${ }^{20}$ It must continue to be repeated: after Nostra Aetate, Catholics learned that proselytism is no longer necessary or desirable for their Jewish older brothers. This is why St John Paul II said that proselytism is "an attempt to do away with one's own brother". ${ }^{21}$ In order to provide an alternative account from D'Costa, I would like to examine briefly the back story of this shift away from proselytism in the formulation of Nostra Aetate and the role Rabbi Heschel had during this process.

15 This tendency is discouraged in a statement issued in 2009 by the US Catholic Bishops: "Jewish covenantal life endures till the present day as a vital witness to God's saving will for His people Israel and for all of humanity" and that Catholic-Jewish dialogue "has never been and never will be used by the Catholic Church as a means of proselytism", nor is it "a disguised invitation to baptism" [13] USCCB. Statement of Principles for Catholic-Jewish Dialogue. Available online: http://www.usccb.org/beliefs-and-teachings/ecumenical-and-interreligious/jewish/upload/Statementof-Catholic-Principles-for-Catholic-Jewish-Dialogue-2009.pdf (accessed on 17 March 2016). For more, see [14] Never Revoked: Nostra Aetate as Ongoing Challenge for Jewish-Christian Dialogue. Edited by Marianne Moyaert and Didier Polleyfeyt. Grand Rapids: Eerdmans, 2010.

16 D'Costa 2014: 135. [7]

17 Ibid. D'Costa himself admits that the use of the "shoulder to shoulder" phrase from Zephaniah 3:9 "avoids any sense of proselytizing and it avoids making any decision on exegetically disputed aspects of Romans 11:25, especially the means of the Jewish [sic] coming in" (D'Costa 2014: 137) ([7], p. 137). For a response from a Jewish perspective, see [15] Edward Kessler's reply to D'Costa in Theological Studies 73: 3 (2012) 614-29.

18 For more on the historical development and the different conceptions and usages of "mission", see [16] David J. Bosch. Transforming Mission: Paradigm Shifts in Theology of Mission, American Society of Missiology Series No. 16. Maryknoll: Orbis Books, 1991, chap. 12. See also [17] Andrew F. Walls. The Missionary Movement in Christian History: Studies in the Transmission of Faith. Maryknoll: Orbis Books, 1996.

19 For more, see [18] Avery Dulles. "Covenant and Mission." America (21 October 2002), pp. 8-11. The article includes responses by Mary Boys, Philip Cunningham, and John T. Pawlikowski. Available online: http://americamagazine.org/ issue/408/article/covenant-and-mission (accessed on 2 May 2016). For more about this debate, see the relevant essays in [19] Berger, ed. Trialogue and Terror: Judaism, Christianity, and Islam after 9/11.

20 For more, see [20] Joseph Fitzmeyer's Anchor Bible commentary on Romans. New York: Doubleday, 1993, p. 862.

21 Cited in Connelly 2012: 287. [8] In 1977, Tommaso Federici prepared a paper that explicitly rejected proselytism for the Committee for Catholic-Jewish relations, but this document was not adopted as official policy [21] Tommaso Federici. "Study Outline on the Mission and Witness of the Church." Available online: https://www.bc.edu/content/dam/files/ research_sites/cjl/texts/cjrelations/resources/articles/Federici.htm(accessed on 17 March 2016). 


\section{Bringing Rabbi Heschel Back into the Story}

One detail that is suppressed in D'Costa's account of the formulation of Nostra Aetate is the important role played by the philosopher and theologian, Rabbi Abraham Joshua Heschel (1907-1972). ${ }^{22}$ It is necessary to appreciate the role of Rabbi Heschel, especially since some scholars, like $\mathrm{D}^{\prime} \mathrm{Costa}$, have reduced the contribution that Heschel made during this time merely to providing Catholics with feedback about how Jewish people felt. ${ }^{23}$ Yet, without Rabbi Heschel it is doubtful that Nostra Aetate would have taken the shape that it did. After Heschel's rightful protest, the final version of Nostra Aetate did not include the earlier proselytizing remarks regarding the conversion of the Jewish people as the Christian hope.

In August 1961, Cardinal Bea set up his first commission to identify the relevant dogmatic, moral, and liturgical principles to make concrete proposals toward the formulation of Nostra Aetate. By November, Bea was already in conversation with Rabbi Heschel because Heschel had supplied Bea with a draft of what should be involved regarding any Catholic declaration on Jewish people-namely, a condemnation of any accusation of Jews killing God (deicide), and to drop all references to Jewish people joining the Church. For Heschel, the problem was not that Judaism was incompatible with Christianity, but rather that the proselytizing claims of the Church were at odds with the integrity of the shared spiritual heritage of Judaism and Christianity. This fact in the timeline is often neglected. For instance, in his commentary on Nostra Aetate, Oesterreicher explicitly says that the American Jewish Committee and Abraham Joshua Heschel in particular, "deserve mention, even though [political initiatives] took place at a later stage, and had no influence to speak of on the discussion of the Council Declaration or the form of its text". ${ }^{24}$

Oesterreicher's report is misleading because as a representative of the American Jewish Committee, Heschel was already in conversation with Bea since $1961 .{ }^{25}$ Indeed, Rabbi Heschel was a close friend of Cardinal Bea and Willebrands, and scholars have documented Heschel's influence leading up to the final form of Nostra Aetate. ${ }^{26}$ This took shape in May 1962, when Rabbi Heschel sent a Memorandum to Cardinal Bea outlining the proposed agenda for a meeting with specific proposals for improving the cause for reconciliation between Jews and Catholics:

(1) a full condemnation of anti-Semitism, and any teachings that hold Jews responsible for deicide as sinful.

(2) a full recognition of holiness and faithfulness to the Torah be accorded to Judaism as a distinct feature of Jewish identity that should be preserved and celebrated today.

(3) to maximize efforts to mutually enhance religious literacy among Christians and Jews, through public discussions, research projects, and publications.

(4) that a high-level commission be put together at the Vatican regarding Christian-Jewish relations.

In his official commentary, Oesterreicher reproduces Heschel's "demands" from the May 1962 memo in a footnote, but provides no comment on the contribution of this external, "secular", and

22 D'Costa 2014: 88-89, 132, 135. [7] I am indebted to several conversations with Susannah Heschel for this observation. Abraham Heschel also played a significant role in the anti-war and Civil Rights movements. Martin Luther King, Jr. referred to Heschel as "my rabbi" and there are iconic photos of them marching "shoulder to shoulder" on Selma.

23 D'Costa 2014: 89. [7]

24 Oesterreicher 1967: 16. [11]

25 Oesterreicher 1967: 16 n. 20. [11] Oesterreicher refers to the AJC memo on the image of the Jew in Catholic teaching (June 1961), the memo on anti-Jewish elements in Catholic liturgy (November 1961), and "the memorandum of the rabbi and seminary professor Abraham Joshua Heschel" (May 1962). These documents have been made available online in the [22] American Jewish Committee Archives: http:/ /ajcarchives.org/ajcarchive/DigitalArchive.aspx (accessed on 2 May 2016).

26 For more, see the detailed account in [23] Edward Kaplan. Spiritual Radical. New Haven: Yale, 2007, chaps. 13-14. Kaplan's account follows closely that of [24] Marc Tanenbaum. "Jewish-Christian Relations: Heschel and Vatican Council II." 21 February 1983. Available online: http://www.ajcarchives.org/AJC_DATA/Files/Z582.CV01.pdf (accessed on 17 March 2016). See also, [25] Gary Spruch. Wide Horizons: Abraham Joshua Heschel, AJC, and the Spirit of Nostra Aetate. New York: American Jewish Committee, 2008. 
Jewish element in the formulation of Nostra Aetate. ${ }^{27}$ Heschel's influence is reflected implicitly in the way Oesterreicher reports that despite Cardinal Bea's attempts to keep this wording in the council document, it was eventually dropped in the final draft. ${ }^{28}$

Between 28-31 August 1960, a group of scholars gathered in Apeldoorn that was comprised of Anton Ramselaar (Katholieke Raad voor Israel), Karl Thieme (Freiburger Rundbrief), Paul Demann (Cahiers Sioniens), Jean Roger (Oeuvre de St. Jacques), and Oesterreicher (The Bridge). For Oesterreicher's narrative, it was this group that "formed the prophetic element that over the years prepared a place in the Church, intellectually and spiritually, emotionally and theologically, for the Council Declaration of which they too as yet knew nothing" ([10], p. 12). Later, Oesterreicher presents himself as offering an important position paper in Ariccia on 6-21 April 1961 that refocuses the discussion upon the exegetical insights of Romans 9-11. It is at this point in the story that Oesterreicher begins to insert himself into the plot as an implicit representative of the Church's eschatological aims. ${ }^{29}$

The buffered Vatican mindset during this time is repeated in Oesterreicher's commentary, which creates a narrative that stresses the theological nature of Council deliberations so as to downplay any political maneuvers behind the scenes. The stated reason for this apolitical strategy was to deflect any negative interpretations by Arab governments of a perceived Vatican endorsement of the State of Israel and its political agenda. ${ }^{30}$ However, Cardinal Bea was in conversation with important Jewish voices during this time. For instance, Bea flew to New York to meet privately with Rabbi Heschel at the American Jewish Committee on 31 March 1963 to discuss with Heschel and some others "the basic issues of Jewish concern" regarding Vatican II. In advance of the meeting on 7 March, Heschel had sent to Bea a revised version of his memo from the year before. One notable difference in this version was how Heschel drew to the Cardinal's attention the need to condemn 'sins against charity" - that is, "attributing the worst possible motive" to the intentions of any human being based upon "superficial evidence [and] generalizations". ${ }^{31}$ The timing of this private meeting between Bea and Heschel was crucial because the issues needed to be addressed before 8 September 1963 when the council reconvened. The meeting was meant to last 90 minutes. It was reported to have lasted three hours.

Bea returned to Rome with a new draft of the Council document-significantly influenced by the issues that Heschel brought to his attention. But by 1964, Heschel's memo had been heavily redacted and the penultimate draft had removed the condemnation of proselytism, which was leaked to the New York Times and Herald Tribune (12 June 1964). Because of the controversy surrounding this document, all things looked like this document would be thrown out of the Council process altogether. So Heschel went to the press and he made headlines in Time Magazine (11 September 1964) where he is quoted as saying "As I have repeatedly stated to leading personalities of the Vatican, I am ready to go to Auschwitz any time, if faced with the alternative of conversion or death". It has been said that after Heschel met with Pope Paul VI, the Pope crossed out the line of text with his own pen. ${ }^{32}$

27 Oesterreicher 1967: 17 n. 20. [9]

28 See [26] John M. Oesterreicher. The New Encounter: Between Christians and Jews. New York: Philosophical Library, 1986, pp. 188-92.

29 Oesterreicher 1967: 20-21. [9]

30 Oesterreicher 1967: 18-19. D'Costa repeats Oesterreicher's narrative in this regard, see, D'Costa 2014: 88-89; chap. 3. For Arab responses to the "apolitical" stance of the Council, see [27] Meir Litvak, and Esther Webman. From Empathy to Denial: Arab Responses to the Holocaust. New York: Columbia University Press, 2009, chap. 4. Also see, [28] James L. Fredericks, and Tracy Sayuki Tiemeier, eds. Interreligious Friendship after Nostra Aetate, Interreligious Studies in Theory and Practice. New York: Palgrave Macmillan, 2015.

31 Page 2 of the proposed agenda attached to Rabbi Heschel's private correspondence dated 25 March 1963 to Rabbi Albert Minda.

32 [29] Doris Donnelly. "Lovingly Observant: an interview with Susannah Heschel." Available online: http://americamagazine. org/issue/618/article/lovingly-observant (accessed on 17 March 2016). 


\section{Fifty Years on with Pope Francis}

This essay began with the problem of forgetting the legacy and teaching of Nostra Aetate and the undesirable consequence of proselytism toward Judaism as evidenced by the perspective that continues to resurface with some Catholic theologians like D'Costa. I briefly reviewed the back-story of the document's formulation to reveal how Jewish thinkers like Rabbi Heschel played a key role in the development of Catholic teaching. For St Paul it is to the Jewish people that "belong the adoption, the glory, the covenants, the giving of the Law, the worship, and the promises" (Rom 9:4). After Heschel's contribution, Oesterreicher later revised his argument that the eschatological hope described in Romans 9-11 for unity between Israel and the Church should not be interpreted as a covert endorsement of proselytism (a "mission to the Jews"), but rather "expresses simply and solely the belief that at the end of time, God will gather into union with Himself all who profess His name" ([25], p. 193). It is interesting that $\mathrm{D}^{\prime} \mathrm{Costa}$ aligns himself with the earlier proselytizing views of Oesterreicher before Nostra Aetate, but does not acknowledge Oesterreicher's later abandonment of a mission to Jewish people, as presented by John Connelly. ${ }^{33}$

Still today we might ask ourselves whether or not this legacy has been forgotten altogether, or whether it is still under development. The reigning narrative surrounding the production of Nostra Aetate is often placed solely upon Catholics as the unilateral source. For instance, Massimo Faggioli claims that "The story of Nostra Aetate is a story of leadership in the Church. It was only indirectly a fruit of a collective process of reflection on the relations between Jews and Christians". 34 Yet in his article, it is only in closing that Faggioli mentions anything about Abraham Heschel.

The ambiguity between forgetting a tradition and a development of it resurfaced during Pope Francis" recent visit to the USA. In September 2015, Pope Francis gave a speech that could be read as an attempt to develop the legacy and teaching of Nostra Aetate. ${ }^{35}$ In his speech, Pope Francis reminded us that
the religious dimension is not a private sub-culture. It is part of the culture of any people and any nation. Our various religious traditions serve society primarily by the message they proclaim. They call individuals and communities to worship God, the source of all life, liberty, and happiness. They remind us of the transcendent dimension of human existence and our irreducible freedom in the face of every claim to any absolute power ... Our rich religious traditions seek to offer meaning and direction, "they have an enduring power to open new horizons, to stimulate thought, to expand the mind and heart" (Evangelii Gaudium [33], 256). They call to conversion, reconciliation, concern for the future of society, self-sacrifice in the service of the common good, and compassion for those in need. At the heart of their spiritual mission is the proclamation of the truth and dignity of the human person and human rights.

Speaking from Abraham Lincoln's lectern when he gave the Gettysburg address, the Pope develops a central theme from Nostra Aetate when he highlighted the goal that all religions share in making it "clear that it is possible to build a society where "a healthy pluralism which respects

33 For more, see [30] John Connelly. "The Catholic Church and Mission to the Jews" In After Vatican II: Trajectories and Hermeneutics. Edited by James Heft. Grand Rapids: Eerdmans, 2013, pp. 126-27.

34 [31] Massimo Faggioli. Nostra Aetate after Fifty Years. Available online: http://www.abc.net.au/religion/articles/2015/ 10/30/4342407.htm (accessed on 17 March 2016). In this article, Faggioli asks some important ecclesiological questions in light of Nostra Aetate and indicates a few positive developments that grew out of it, but largely leaves Rabbi Heschel out of the picture until closing paragraph.

35 Pope Francis, Religious Freedom speech at Independence Hall (26 September 2015). ZENIT Staff. [32] Pope's Address in Philadelphia on Religious Freedom. Available online: http://www.zenit.org/en/articles/pope-s-address-in-philadelphiaon-religious-freedom (accessed on 17 March 2016). Although it should be stated that these recent speeches by Pope Francis should be read within a broader context, not only Evangelium Gaudium, but also all of the documents of the Second Vatican Council, such as Nostra Aetate, Gaudium et Spes, Lumen Gentium, and Dignitatis Humanae. 
differences and values them as such"“ (Evangelii Gaudium [33], 255). In this specific context, Pope Francis was referring to the need to welcome immigrants and their gifts as one important way to renew and enrich society. And yet, when he describes the "spiritual mission" and "the call to conversion", he still employs terms that have a very specific connotation to certain audiences-despite his re-directing the meaning of these terms towards the betterment of society and proclaiming the truth, dignity, and fundamental rights of the human person.

However, if we hear Pope Francis in terms of developing Nostra Aetate, we might appreciate the way he draws upon the declaration's assertion that "the Church rejects nothing that is good and holy in those religions" as evidence for the wider religious experience of non-Christians. Likewise, the recognition that non-Catholics can "reflect a ray of that truth which enlightens us all" also points to a knowledge received out of religious kinship. This reinforces an observation made by St Augustine, "No one becomes known except through friendship" 36 and highlights the need to understand the role of religious proclamation in society as that of "becoming known as friends", not proselytism. In this way, we can enrich our own respective traditions through inter-religious dialogue and friendship.

In October 2015, Pope Francis commemorated the 50th anniversary of Nostra Aetate by holding an inter-religious audience in Saint Peter's Square, which coincided with an International Congress at the Pontifical Gregorian University where Cardinal Bea once taught. Cardinal Kurt Koch described this commemoration as "an important contribution to further reflection on that "culture of encounter" between persons, peoples and religions that you have very much at heart". Reflecting upon the achievements of Nostra Aetate ([1965], n. 4), Cardinal Koch reiterated that

In the light of this communion that exists between Jews and Christians in the history of salvation, the Council makes evident the Jewish roots of the Christian faith and acknowledges the great "common spiritual patrimony" to Christians and to Jews. Moreover, the Council deplores all hatred and manifestations of violence against the Jewish people, also by Christians, and condemns all forms of anti-Semitism. ${ }^{37}$

Those who know the back-story of Rabbi Heschel's involvement can appreciate how the Cardinal placed these two points in a prominent light. Cardinal Koch went on to illuminate another point—which had been raised by Heschel—but attributes it to the witness of Pope Francis: "In our days, at a time in which unfortunately new waves of anti-Semitism have arisen, you, Holy Father, remind us Christians incessantly that it is impossible to be a Christian and an anti-Semite at the same time". In his own comments, Pope Francis highlighted the various points that Nostra Aetate had addressed and said that in our time

Indifference and opposition have changed into collaboration and benevolence. From enemies and strangers we have become friends and brothers. The Council traced the way with the "Nostra Aetate" Declaration: "yes" to the rediscovery of the Jewish roots of Christianity; "no" to every form of anti-Semitism and condemnation of all insults, discrimination and persecutions that stem from it. Mutual knowledge, respect and esteem constitute the way that, if it is true in a particular way for the relation with the Jews, is also equally true for relations with the other religions [Zenit 2016] [35].

Pope Francis went on to call for mutually "open and respectful" inter-religious dialogue that worked to enhance the "respect of others" right to life, of their physical integrity, of the fundamental liberties, namely liberty of conscience, of thought, of expression and of religion". Concluding, Pope Francis invited all the representatives of the various religions present to pray for one another in

36 [34] Augustine. De diversis quaestionibus. 71.5; Augustine. Eighty-Three Different Questions. vol. 70, The Fathers of the Church. Washington: Catholic University of America Press, 2002, p. 183.

37 [35] ZENIT Staff. General Audience: On 50 years since Nostra Aetate. Available online: http://www.zenit.org/en/articles/ general-audience-on-50-years-since-nostra-aetate (accessed on 17 March 2016). 
silence reminding them that together the religions can become an important impetus for achieving the common good in society:

Dialogue based on trustful respect can bring seeds of good that in turn become shoots of friendship and collaboration in so many fields, especially in service to the poor, to the little ones, to the elderly, in the reception of migrants, in the care of those that are excluded. We can walk together taking care of one another and of Creation-all believers of all religions. Together we can praise the Creator for having given us the garden of the world to cultivate and protect as a common good, and we can undertake shared projects to fight poverty and ensure to every man and woman fitting conditions of life.

In December 2015, reflecting upon his trip to Africa, Pope Francis gave another general audience that built upon the message he presented during the 50th anniversary of Nostra Aetate. Speaking to a group of young people, Pope Francis reiterated the words of his namesake, St Francis of Assisi: the missionary spirit is not proselytizing" but rather that "witness is the great heroic missionary spirit of the Church. Proclaim Jesus Christ with your life!" Pope Francis described the missionary as the one who brings "love, humanity, and faith to other countries. Not to proselytize, no. That is done by those who are seeking something else. Faith is preached first by witness and then through words. Slowly" ${ }^{38}$

\section{Concluding Remarks}

In light of recent developments pertaining to the 50th anniversary of Nostra Aetate and Pope Francis" call for more dialogue between traditions in terms of friendship, it is remarkable that the Commission for Religious Relations issued a document in December 2015 entitled, "The Gifts and Calling of God are Irrevocable". ${ }^{39}$ An in-depth analysis of this document about the status of Catholic-Jewish dialogue lies beyond the scope of this essay, but its existence is unthinkable without the legacy of Abraham Heschel. ${ }^{40}$ Although the Commission's recent document does not carry magisterial status juridically, the theological reflection it contains upon Nostra Aetate does carry juridical weight as reflection upon a Council document. On the other hand, it took about one month for Pope Francis to begin using phrases from this document on his visit to the synagogue in Rome. ${ }^{41}$

The Commission's document recognizes the special status of Catholic-Jewish dialogue on the basis of the Jewish roots of Christianity and the indivisibility of the Word of God and thus "the enduring role of the covenant people of Israel in God's plan of salvation" ([37], n. 43)—despite differing theological interpretations in each tradition. Chapter six is significant especially because it affirms both the Church's responsibility to bear witness to their faith in Christ, but also that the Church repudiates any proselytism, conversion, and mission toward the Jews. The document explicitly says that "the Catholic Church neither conducts nor supports any specific institutional mission work directed towards Jews" ([37], n. 40).

38 [36] Pope Francis. “General Audience.” 2 December 2015. Available online: http://w2.vatican.va/content/francesco/en/ audiences/2015/documents/papa-francesco_20151202_udienza-generale.html (accessed on 17 March 2016).

39 [37] Commission for Religious Relations with the Jews. The Gifts and the Calling of God are Irrevocable (Rom 11:29). Available online: http://www.vatican.va/roman_curia/pontifical_councils/chrstuni/relations-jews-docs/rc_pc_ chrstuni_doc_20151210_ebraismo-nostra-aetate_en.html\#6._The_Church $\backslash$ T1 $\backslash$ textquoterights_mandate_to_evangelize_ in_relation_to_Judaism (accessed on 17 March 2016).

40 For more on post-Vatican II developments in Catholic-Jewish relations, see relevant essays in [38] Gilbert S. Rosenthal, ed. A Jubilee for All Time: The Copernican Revolution in Jewish-Christian Relations. Eugene: Wipf and Stock, 2014. See also, [39] Michael S. Kogan. Opening the Covenant: A Jewish Theology of Christianity. Oxford: Oxford University Press, 2008, chap. 7.

41 [40] Vatican Radio. Pope Francis calls on Catholics and Jews to work together for peace. Available online: http://www. news.va/en/news/pope-francis-calls-on-catholics-and-jews-to-work-t (accessed on 17 March 2016). Pope Francis said that "the Declaration Nostra Aetate, has indicated the way: "yes" to rediscovering Christianity's Jewish roots; "no" to every form of anti-Semitism and blame for every wrong, discrimination and persecution deriving from it." Nostra Aetate explicitly defined theologically for the first time the Catholic Church's relations with Judaism. Of course it did not solve all the theological issues that affect us, but we it provided an important stimulus for further necessary reflections. In this regard, on 10 December 2015, the Commission for Religious Relations with the Jews published a new document that addresses theological issues that have emerged in recent decades since the promulgation of "Nostra Aetate". 
The title of the Commission's document is theologically significant because it refers to the integral role that both Judaism and Christianity have currently in the mystery of salvation history. The document defines the goal of dialogue in terms of bringing humanitarian aid together as a blessing to the world that grows out of fraternal dialogue, mutual respect and learning, whilst seeking reconciliation and promoting justice and peace on earth by opposing anti-Semitism ([37], nn. 46-49). The document also calls for Catholic educational institutions and seminaries to integrate into their curricula not only Nostra Aetate, but also all subsequent documents regarding the implementation of this conciliar declaration ([37], n. 45). Responding to the Commission's document, Jewish theologian Edward Kessler said

As a result of a soul change, epitomised by Nostra Aetate, the Roman Catholic Church shifted from what was, for the most part, a need to condemn Judaism to one of a condemnation of anti-Judaism. This led not to a separation from all things Jewish but in fact, to a closer relationship with "the elder brother". The new document, which I welcome and commend, reminds Christians of this sibling relationship as it sets out a theological agenda for future discussions. $^{42}$

It is no coincidence that the document issued recently by the Commission maps on directly to the concerns raised by Rabbi Heschel's 1962 memo to Cardinal Bea. In the first part of this essay, I emphasized-against the grain of recent scholarship—how important Rabbi Abraham Joshua Heschel was for the reconsideration of Judaism during the Second Vatican Council and the formulation of Nostra Aetate. It is in this particular moment in history that we see Rabbi Heschel explicitly endorsing and bringing about a reform within Catholic theology rooted in the shared prophetic tradition.

In the second part of this essay, I highlighted some recent shifts in Roman Catholic discourse with the papacy of Pope Francis and contextualized these remarks in light of Rabbi Heschel's legacy. Space does not permit to clarify further the links between the story of Heschel's contribution and ongoing development of the directions set in Nostra Aetate. However, this could be explored using the theme of "personal encounter" since Rabbi Heschel made such a significant contribution partly through the friendships he had established with Catholics, like Cardinal Bea himself. As we have seen, Pope Francis has recently renewed this emphasis on the role of friendship and personal encounter as central to interfaith and interreligious relations. In this way, this renewed emphasis on friendship and personal encounter underscored by the present pope firms up the link between the back story of Rabbi Heschel's contribution and the ongoing development of Nostra Aetate.

As in the past, it would be tempting for Catholic scholars to place the responsibility of this more enlightened form of religious pluralism squarely upon the shoulders of the Pope. But I have suggested that at important junctures in history, it has been non-Catholics that have re-oriented their perspective when it comes to Judaism, and it is only very recently that this is being recognized at the highest levels in Rome. One could think that by endorsing religious pluralism, this might also elicit a further disengagement among the different religions with the world. But the legacy of Abraham Heschel stands as an important testimony to the contrary; because without Heschel's prophetic voice, it would be very difficult to imagine the existence of Nostra Aetate and the positive subsequent developments that we are witnessing today. This is something that should not continue to be forgotten by contemporary Catholic scholars writing about the achievements of the Second Vatican Council. ${ }^{43}$

Conflicts of Interest: The author declares no conflict of interest.

42 [41] Edward Kessler. "Reflections from a European Jewish Theologian." Available online: http://www.ccjr.us/dialogikaresources/documents-and-statements/analysis/crrj-2015dec10/1366-kessler-2015dec10 (accessed on 17 March 2016). For more, see the recent address by [42] Pope Francis to the International Council of Christians and Jews in June 2015. Available online: http://www.ccjr.us/dialogika-resources/documents-and-statements/roman-catholic/francis/1337-address-tothe-international-council-of-christians-and-jews (accessed on 30 May 2016).

43 I am grateful for the helpful comments provided by two anonymous reviewers. 


\section{References}

1. “Nostra Aetate." Available online: http://www.vatican.va/archive/hist_councils/ii_vatican_council/ documents/vat-ii_decl_19651028_nostra-aetate_en.html (accessed on 3 June 2016).

2. John T. Pawlikowski. "Defining Catholic Identity against the Jews: Pope Benedict XVI and the Question of Mission to the Jewish People." In Trialogue and Terror: Judaism, Christianity, and Islam after 9/11. Edited by Alan L. Berger. Eugene: Cascade Books, 2012, chap. 7.

3. Harold Kasimow. Interfaith Activism: Abraham Joshua Heschel and Religious Diversity. Eugene: Wipf and Stock, 2015, esp. chap. 8.

4. Harold Kasimow, and Byron L. Sherwin, eds. No Religion Is an Island: Abraham Joshua Heschel and Interreligious Dialogue. Maryknoll: Orbis, 1991.

5. Michael Signer's essay “Body and Soul: Interreligious Dialogue.” In Abraham Joshua Heschel: Philosophy, Theology and Interreligious Dialogue. Edited by Stanislaw Krajewski and Adam Lipszyc. Wiesbaden: Harrassowitz, 2009, pp. 181-87.

6. Reuven Kimelman. "Rabbis Joseph B. Soloveitchik and Abraham Joshua Heschel on Jewish-Christian Relations." Modern Judaism 24 (2004): 251-71. [CrossRef]

7. Gavin D'Costa. Vatican II: Catholic Doctrines on Jews and Muslims. Oxford: Oxford University Press, 2014.

8. John Connelly. From Enemy to Brother: The Revolution in Catholic Teaching on the Jews (1933-1965). Cambridge: Harvard University Press, 2012.

9. "Non abbiamo bisogno." Available online: http://w2.vatican.va/content/pius-xi/en/encyclicals/ documents/hf_p-xi_enc_29061931_non-abbiamo-bisogno.html (accessed on 3 June 2016).

10. "Mit brennender Sorge." Available online: http://w2.vatican.va/content/pius-xi/en/encyclicals/ documents/hf_p-xi_enc_14031937_mit-brennender-sorge.html (accessed on 3 June 2016).

11. John Oesterreicher. "Declaration on the Relationship of the Church to Non-Christian Religions." Commentary on the Documents of Vatican II 3 (1967): 1-136.

12. Massimo Faggioli. John XXIII: Medicine of Mercy. Collegeville: Liturgical Press, 2014, chap. 4.

13. USCCB. "Statement of Principles for Catholic-Jewish Dialogue." Available online: http: //www.usccb.org/beliefs-and-teachings/ecumenical-and-interreligious/jewish/upload/Statement-ofCatholic-Principles-for-Catholic-Jewish-Dialogue-2009.pdf (accessed on 17 March 2016).

14. Never Revoked: Nostra Aetate as Ongoing Challenge for Jewish-Christian Dialogue. Edited by Marianne Moyaert and Didier Polleyfeyt. Grand Rapids: Eerdmans, 2010.

15. Edward Kessler's reply to D'Costa in Theological Studies 73 (2012): 614-29.

16. David J. Bosch. Transforming Mission: Paradigm Shifts in Theology of Mission, American Society of Missiology Series No. 16. Maryknoll: Orbis Books, 1991, chap. 12.

17. Andrew F. Walls. The Missionary Movement in Christian History: Studies in the Transmission of Faith. Maryknoll: Orbis Books, 1996.

18. Avery Dulles. “Covenant and Mission." America, 21 October 2002, pp. 8-11.

19. Trialogue and Terror: Judaism, Christianity, and Islam after 9/11. Edited by Alan L. Berger. Eugene: Cascade Books, 2012.

20. Joseph Fitzmeyer. Romans. New York: Doubleday, 1993.

21. Tommaso Federici. "Study Outline on the Mission and Witness of the Church." Available online: https:/ /www.bc.edu/content/dam/files/research_sites/cjl/texts/cjrelations/resources/articles / Federici.htm (accessed on 17 March 2016).

22. "American Jewish Committee Archives." Available online: http://ajcarchives.org/ajcarchive/ DigitalArchive.aspx (accessed on 2 May 2016).

23. Edward Kaplan. Spiritual Radical. New Haven: Yale, 2007.

24. Marc Tanenbaum. "Jewish-Christian Relations: Heschel and Vatican Council II." 21 February 1983. Available online: http://www.ajcarchives.org/AJC_DATA/Files/Z582.CV01.pdf (accessed on 17 March 2016).

25. Gary Spruch. Wide Horizons: Abraham Joshua Heschel, AJC, and the Spirit of Nostra Aetate. New York: American Jewish Committee, 2008.

26. John M. Oesterreicher. The New Encounter: Between Christians and Jews. New York: Philosophical Library, 1986.

27. Meir Litvak, and Esther Webman. From Empathy to Denial: Arab Responses to the Holocaust. New York: Columbia University Press, 2009. 
28. James L. Fredericks, and Tracy Sayuki Tiemeier, eds. Interreligious Friendship after Nostra Aetate, Interreligious Studies in Theory and Practice. New York: Palgrave Macmillan, 2015.

29. Doris Donnelly. "Lovingly Observant: an interview with Susannah Heschel." Available online: http: / /americamagazine.org/issue/618/article/lovingly-observant (accessed on 17 March 2016).

30. John Connelly. "The Catholic Church and Mission to the Jews." In After Vatican II: Trajectories and Hermeneutics. Edited by James Heft. Grand Rapids: Eerdmans, 2013.

31. Massimo Faggioli. "Nostra Aetate after Fifty Years." Available online: http://www.abc.net.au/religion/ articles/2015/10/30/4342407.htm (accessed on 17 March 2016).

32. ZENIT Staff. "Pope's Address in Philadelphia on Religious Freedom." Available online: http://www.zenit. org/en/articles/pope-s-address-in-philadelphia-on-religious-freedom (accessed on 17 March 2016).

33. "Evangelii Gaudium." Available online: http://w2.vatican.va/content/francesco/en/apost_exhortations/ documents/papa-francesco_esortazione-ap_20131124_evangelii-gaudium.html (accessed on 3 June 2016).

34. Augustine. "De diversis quaestionibus. 71.5; Augustine. Eighty-Three Different Questions. vol. 70." In The Fathers of the Church. Washington: Catholic University of America Press, 2002, p. 183.

35. ZENIT Staff. “General Audience: On 50 years since Nostra Aetate." Available online: http://www.zenit.org/ en/articles/general-audience-on-50-years-since-nostra-aetate (accessed on 17 March 2016).

36. Pope Francis. "General Audience." 2 December 2015. Available online: http://w2.vatican.va/content/ francesco/en/audiences/2015/documents/papa-francesco_20151202_udienza-generale.html (accessed on 17 March 2016).

37. Commission for Religious Relations with the Jews. "The Gifts and the Calling of God are Irrevocable (Rom 11:29)." Available online: http://www.vatican.va/roman_curia/pontifical_councils/chrstuni/ relations-jews-docs/rc_pc_chrstuni_doc_20151210_ebraismo-nostra-aetate_en.html\#6._The_Church \T1 textquoterights_mandate_to_evangelize_in_relation_to_Judaism (accessed on 17 March 2016).

38. Gilbert S. Rosenthal, ed. A Jubilee for All Time: The Copernican Revolution in Jewish-Christian Relations. Eugene: Wipf and Stock, 2014.

39. Michael S. Kogan. Opening the Covenant: A Jewish Theology of Christianity. Oxford: Oxford University Press, 2008, chap. 7.

40. Vatican Radio. "Pope Francis calls on Catholics and Jews to work together for peace." Available online: http:/ / www.news.va/en/news/pope-francis-calls-on-catholics-and-jews-to-work-t (accessed on 17 March 2016).

41. Edward Kessler. "Reflections from a European Jewish Theologian." Available online: http://www.ccjr.us / dialogika-resources/documents-and-statements/analysis/crrj-2015dec10/1366-kessler-2015dec10 (accessed on 17 March 2016).

42. Pope Francis. "Address to the International Council of Christians and Jews." Available online: http:/ / www.ccjr.us/dialogika-resources/documents-and-statements/roman-catholic/francis/1337address-to-the-international-council-of-christians-and-jews (accessed on 30 May 2016).

(C) 2016 by the author; licensee MDPI, Basel, Switzerland. This article is an open access article distributed under the terms and conditions of the Creative Commons Attribution (CC-BY) license (http://creativecommons.org/licenses/by/4.0/). 